\title{
New Students Admission Management Analysis In Sdit Ki Hajar Dewantoro, Tambun Selatan, Kab. Bekasi
}

\author{
Diyah Yuli Sugiarti and Dewi Aryanti \\ \{diyah.ys@unismabekasi.ac.id ${ }^{1}$, dewi.aryanti02@gmail.com² ${ }^{2}$, \\ Unisma, Bekasi
}

\begin{abstract}
The aim if this study is to analyze the management of new student admissions at SDIT Ki Hajar Dewantoro. The problem found are: school management has not run optimally, there is no planning for all school activities and programs, promotion for school isn't maximal yet, it is not referring to RKJP (long term work plan) and RKJM (medium-term work plan) however; the strategy made by the school is not on the right target, it has not involved the community around the school: admission process of new students to graduation has not been maximized, as evidenced by the low number of enrolment new students every year. This study uses a qualitative descriptive research method. Qualitative descriptive research is intended to describe a situation or phenomena as they are, without being made up. The technique of collecting/recording data is by observation, interviews, and documentation. Data analysis uses qualitative data analysis that the process of searching and compiling data was done systematically which obtained from interviews, field notes, and other materials so that they are accessible to understand and that they can be informed to others. The technique of checking the validity of the data using triangulation, researchers can check their findings by comparing it with various sources, methods, or theories. The results of the study that uses SWOT analysis for new student admissions management by looking at strengths, weaknesses, opportunities, and threats by doing so the school will understand and will do the input to increase the number of new students admitted for the coming year.
\end{abstract}

Keywords: admission of new students, management analysis

\section{Introduction}

New Student Admission Management (PPDB) is conducted to provide services to the community, especially for students can be achieved well. Public trust in educational institutions needs to be improved.

For this reason, approachment systems need to improve efficiency and effectiveness. Educational institutions are becoming more complex and challenging to manage. Traditional methods in management are no longer sufficient to solve problems; It needs information technology support. Moreover, New Student Admission (PPDB) is not only distributing brochures for promotion but also use information technology so that anyone who needs information can get it from the website. The website will provide complete information about the school, the process of new 
student admission, a school program that has been implemented and the school achievement of SDIT Ki Hajar Dewantoro.

Without Information technology, it is difficult to make improvement optimally. And also, good coaching and cooperation with alumni and alumni parents must be well-done so that they can become own marketing for the school by giving good information personally to the people they know. SDIT Ki Hajar Dewantoro has the potential to develop in its new students as long as the new student admissions management is supported by all components

Another important factor that must be done by schools is to continually communicate, with education officials in their working area. Thus, various problems can immediately be discussed and resolved. Likewise with the existence of communities around the school and the existence of schools that should interact and synergize so that the school will develop well and be accepted by the community. On the contrary, the community will also be benefitting from qualified graduates who supported by various good program activities since the beginning of the school; this is also related to the acceptance of new students,

The school also must be supported by professional and high competence teachers The comfort factor of students from the beginning of entering the school to learning process will also influence the number of new students admission since this school passes through a mental rehabilitation institution.

The point is, the community is positioned as a customer of the school must be well served by the school so that the community can provide maximum support in the development of the school. The school must be able to compile and explain school programs that are very rational and easy to understand for parents and the surrounding community. By doing so, the public will know well the various good and superior school activities for the community. The society who want to help the school will supervise the program and develop it if it is possible.

School programs are carried out in the form of extracurricular or superior religious programs, which can involve various components of the community who are experts in their fields to participate in building school programs, as an additional school identity. The clearer information about a school that is conveyed to the community, the more sympathy will be drawn from the community, so that the acceptance of new students at SDIT Ki Hajar Dewantoro can increase.

Thus the problems that exist in school are (1) 1. How does the school management develop school programs?, (2) What strategies can be made by the school for PPDB?, (3) What services should provide by the school from the beginning of PBD process to graduation?

The acceptance of new students in an educational institution (school) is essentially a searching process; it is determining and attracting applicants who can become students in the relevant educational institutions (schools). Admission is a process of data collection and service for students who are just entering school after they meet the requirements set by the school. The steps for receiving new students are as follows (1) Establishment of a new student admission committee, (2) Making and installing PPDB announcements, (3) The student selection stage: Through tests or exams, Through tracing talent and abilities, Based on the STTB value or UAN value.

The existence of the students' are very much needed, especially for the implementation of educational activities in schools, students are the subject and object in the process of transformation necessary knowledge and skills. Therefore, the existence of students is not just to fulfill the needs, but must be part of the needs of educational institutions (schools). 
This means that it requires management of quality students for educational institutions (schools) themselves. So that students can grow and develop by the physical potential, intellectual intelligence, social, emotional, and psychological of the students. Services to students start from the admission of new students, placement, coaching, development, and the service go through until they graduate from the school. Schools must have student service units so that the quality and quality of culture can be created well.

Schools must have strategic management, school management and analysis of strengths, weaknesses, opportunities, and threats (swot analysis) that are good for school progress. Strategic management is an organization containing three elements, namely analysis, decision, and action. Strategic management relates to the review of strategic goals (vision, mission, and objectives) along with internal and external environmental analysis.

Furthermore, top management must make strategic decisions. After making a strategic decision, the next is to take actions (actions). The organization must take action to implement the strategy. This requires leaders to allocate resources and organize them with the capabilities they have to apply the strategies that have been formulated/decided (Sampurno, 2013).

The primary school management is the activity of managing elementary schools. The primary school management has two aspects, namely: internal management and external management. The internal management of primary schools includes recognition, library management, laboratories, buildings, as well as other physical and material resources, financial resources, examinations and promotions, relationships with colleagues and students. External management includes relations with the community, departments, and people, as well as parties related to the determination and function of the school. School management is a human effort that works together, even though the principal is the school manager, cooperation between teachers, parents, students, and community members is essential so that the school can be managed effectively (Marini, 2014).

While the SWOT analysis describes what becomes; (1) strengths / advantages possessed by the school (Strength), (2) weaknesses that need to be addressed, (3) opportunities that are in the school for the future (4) as well as real challenges that faced by school (Rangkuti, 2016). Thus what has been planned in the beginning can run optimally.

\section{Method}

The study was conducted at SDIT Ki Hajar Dewantoro, having his address at Kp. Pulo RT. 04/037 Sumber Jaya Village, South Tambun District, Bekasi Regency, West Java Province, under the auspices of the Bekti Sumber Jaya Foundation, Tambun Selatan. The time of this study was carried out in two stages at the pre-observation and observation stage in June 2018, and the field research stage in July 2018 and the preparation of the research report was conducted in August 2018.

The foundation has a different level school they are: Integrated Islamic Primary School, Integrated Islamic Junior High School (SMPIT) and High School (SMAIT) and also there is Islamic Boarding Schools. By looking at the objectives of the school: making adult students responsible for their choices, forming students to understand the Law of Allah with a spirit of patience,Persistence and 'tawakal' in achieving a safety life in the world and in the hereafter, it can be concluded that the goal is to shape the "character" of the children, from the management perspective it was not 
maximal yet, as the management of new student admissions, that can be seen by looking at the data provided by the school for all study groups (classes) from grade 1 (one) to grade 6 (six) only 55 pupils, this school have more than 55 students, if they have the right management. The school should be managed well by stakeholders, considering that there is still a lot of capacity in this school.

The research method used by researchers is qualitative descriptive research method. Descriptive research is intended to describe a situation or phenomena as they are (Creswell, 2012a, 2012b; Sudaryono, 2014).

The data and data sources were obtained from school principals, vice principal of curriculum, student affairs, teachers, parents of alumni and community leaders. By using data collection/recording techniques; observation, interview, and documentation.

Kualitatif Data analysis techniques using Qualitative data. It is analyzed the process of searching and systematically analyzing data obtained from interviews, field notes, and other materials so that they will be understood easily. So that they can be informed to others. According to Miles and Huberman, there are three kinds of activities in qualitative data analysis, namely: data reduction, data model and conclusion/verification of conclusions (Sugiyono, 2015). Data analysis in qualitative research was carried out before entering the field. The analysis has begun since formulating data and explaining the problem, before plunging into the field and continuing until the writing of the research results. But in qualitative research, data analysis is more focused during the process in the field together with data collection.

Test the validity of the data using Triangulation of data (Creswell, 2012b, 2012a; Moleong, 2004), In the field of research activities, researchers propose various variations of questions to informants then record them in field notes from observations and interviews. Field notes from interviews consist of various data sources, then compare the results of interviews to be re-checked, and are drawn to conclusions. For this reason, researchers carry it out by the way; (1) submit various variations of questions, (2) Check with various data sources, (3) Use various methods to verify data trustworthiness.

\section{Result and Discussion}

School management in planning school activities and programs, including in-school promotion is still not optimal, because it is not yet supported by information technology, there are no unique characteristics / superior school programs. It is not referring to the term work plan/midterm work plan yet. According to Arita Marini, elementary school management is the activity of managing or managing elementary schools. The primary school management has two aspects, namely: internal management and external management. Primary school management includes activities. Planning all school activities and programs, including school promotion

According to Nanang Fatah, planning is the process of determining the goals or objectives to be achieved and determining the path and resources needed to achieve that goal as efficiently and effectively as possible. In planning, there are three activities, one with the other can not be separated in the planning process (1) Formulation of objectives that want to be achieved, (2) Selection of programs to achieve that goal, and (3) Identification and deployment of sources whose numbers are always limited. 
Whereas according to Jejen Musfah, planning is: the existence of a work program or program of activities for the short, medium, and long term as well as school work plans. The objectives and benefits of the program: for what a program is implemented, and what impacts or results will be obtained by the institution.

According to Bedjo Sujanto, school programs carried out in the form of extracurricular and superior school programs as an additional identity for the school. With the existence of a superior school identity/program, it will make parents interesting to register their sons/daughters to these schools and become an attraction in school promotion. The more precise information about a school that is conveyed to the community will further attract sympathy from the community.

The strategies made by the school in accepting new students have not focused on strategic goals (vision, mission, and school goals). The school has not involved the community near the school, the school does not establish good relations/cooperation with PAUD / TK / BIMBA around the school environment, and has not cooperated with parents of alumni, which they can be effective marketing for schools. According to Sampurno, strategic management relates to an analysis of strategic goals (vision, mission, and objectives) along with internal and external environmental analysis.

In terms of marketing or promotion we recommend schools steps below:

a. Inform the public about school programs through websites or information technology to make it easier for parents to register at the school.

b. Establishing good relationships with TK / PAUD / BIMBA around the school and with alumni and alumni parents and the community around the school, because they are strong marketing for word of mouth promotion. The relationship between the school and the community according to Bedjo Sujanto can be improved through various alumni networks or by cooperating with community leaders who have wide influence in their area, and the school opens opportunities for community leaders to become "teachers" regularly in various school activities. Some alumni may have become government officials, entrepreneurs, lecturers, and various other positions and professions in the community, whose abilities can be utilized to develop knowledge and skills in schools. Especially for the development of teachers and students, and as a place for school promotion as well

c. Hold competitions at school then present school programs.

d. Considering economic ability of people around the school, the cost of education must be affordable / relatively cheap compared to other IT schools.

There must be a solution that can overcome the obstacles so that the initial goals of the school can be carried out well for in the future

The services provided by the school from the beginning of the new student admission process to graduation, the existence of a sense of security for the school community needs to be provided by the school because the school crosses road access to mental rehabilitation institutions

According to $\mathrm{Hj}$. Sukarti Nasihin and Sururi, components of students' existence are very much needed, especially that the implementation of educational activities in schools, students is the subject as well as the object in the process of transformation of the necessary knowledge and skills. Therefore, the existence of students is not just to fulfill the needs, but must be part of the needs of educational institutions (schools) This means that it requires management of students for educational institutions (schools) themselves. So that students can grow and develop by the physical potential, intellectual intelligence, social, emotional, and psychological of students. 
In his book Bedjo Sujanto said that: service to students starts from the acceptance of new students, placement, coaching, development until they graduate from the school. A safe and orderly school environment, with people who have a high level of concern for school development and their environment, makes managing schools continue to have an optimistic attitude and high expectations for the condition of the school.

The harmonious relationship between the school and the community/parents will also support the creation of a calm and good school climate so that it can be a spirit for the progress of the community it serves.

Schools must improve the quality of service to students who are still studying at school or to alumni so that students can become strong marketing in promoting their schools if they get excellent service from school and have a good impression. Not only that, it is better if the school has an office that is provided for alumni administrators, which will facilitate communication between school administrators and alumni administrators. If the relationship between the school and alumni is well established, the school can develop more through the role of the alumni, one of which helps in terms of school promotion Schools must have a SWOT Analysis so that the school can analyze its internal and external conditions. According to Freddy Rangkuti, the SWOT analysis explained what became (1) strengths / superior of schools (Strenght), (2) weaknesses that need to be overcome, (3) opportunities in the school for the future, and (4) and the real challenges faced by the school.

\section{Conclusion}

After researching SDIT Ki Hajar Dewantoro about Management Analysis of New Student Admissions, it can be concluded that::

School management make plans for all school activities and programs including; the existence of school programs as distinctive features of schools / superior programs, promotion of schools, or managing schools, how schools implementing their work plans, both long, medium and short term so that the objectives can run optimally in accordance with the initial plan, as well as cooperation efforts in school management between school principals, teachers, parents, students, and the community so that schools can be managed effectively.

Having strategic management. Which relates to the analysis of strategic goals (vision, mission, and objectives) along with an internal and external environmental analysis

School services to students should be from the beginning of the new student admission process to graduation, how schools provide security, placement, guidance, development until they graduate from the school, a harmonious relationship between school and community/parents can be a spirit for the progress of the people it serves.

\section{Reference}

